UDK $340.6+343$

\title{
GENDER DIFFERENTIFICATION OF FACTOR CRITERIA OF DERMATOGLIPHIC PARAMETERS OF MIDDLE AND PROXIMAL PHALANGES OF THE FINGERS IN THE PERSON WHICH BELONGING TO THE LEMKO ETHNIC- TERRITIRIAL GROUPS
}

\author{
Kotsyubnska Yu. Z. \\ Ivano-Frankivsk National Medical University
}

\begin{abstract}
Resume. The proposed article presents data obtained in the study of gender differentiation the dermatoglyphics parameters of the middle and proximal phalanges of fingers of the hands of persons belonging to Lemko ethnoterritorial group. And also proposed the possibility of using the data obtained in order to predict the phenotypology of an unknown person.

Keywords. Dermatoglyphical parameters, ethnodermatoglyphics, criteria of Spirman.
\end{abstract}

The structure of papillary relief is highly informative, readily accessible for quantitative and qualitative study, is the subject of studying a range of medical and non-medical sciences.

The dermatoglyphical method is widely used in conducting research on ethno-related issues. One of the scientists who used the dermatoglyphical method in anthropological studies is Hight G. L. [1], who studied the dermatoglyphical parameters of the peoples of the Caucasus and Transcaucasia. Namely, in her work 1974-75rr. («Dermatoglyphics of the peoples of Central Asia in connection with problems of their origin») highlighted the racogenic, ethnopopulative connections of the population of the Caucasus, Central Asia and the South of the European part of the USSR. [2]

A great contribution in this direction was made by Sidorenko AG [3]. He conducted a comprehensive study of dermatoglyphics of the palms, which allowed him to identify racial and sexual differences, depending on the quantitative and qualitative indicators, taking into account the topography of triadious and volary image, as well as the presence or absence of the main and additional triadious; has established a significant correlation in the manifestation of rare dermatological features between the palms of children and true parents.

Regarding the Ukrainian ethnodermatoglific, SV Segeda [4] made a significant contribution to its development, which studied the differentiation of the population of Ukraine by dermatoglyphical parameters. Based on the data obtained, he analyzed the variations of the main features of this system and identified local dermatoglyphical variants (complexes) on the territory of Ukraine (northern, central and southern). Using the data obtained during the study, he identified clear dermatoglyphical parameters that are characteristic of each of the complexes and made a comparison with ethnoterritorial groups living in neighboring territories. This allowed him to highlight the general dermatoglyphical parameters of Ukrainians against the background of other ethnic groups living in Europe and Asia.

Unfortunately, at the present time almost unexplored correlations between the dermatoglyphical parameters of middle and proximal phalanges of the fingers [5] and anthropometric parameters.

The purpose of our study was to study the possibility of predicting the phenotypology of an unknown person, based on the use of dermatoglyphical parameters of middle and proximal phalanges of the fingers.

The object of the study was the correlation between dermatoglyphical and anthropometric parameters in the female (26) and male (25) gender groups living in the Ivano-Frankivsk region and belonging to the Lemko ethno-territorial group.

Methods of research used during the study are: anthropometric, dermatoglyphical and statistical analysis. Statistical analysis was conducted with the help of nonparametric method of Spirman (Spearman rank R) [6] and Multivariate Regression Analysis (Multiple Regression) [7]. Study was conducted with the help of statistical analysis stable correlations between dermatogliphical parameters of middle and proximal phalanges of fingers and anthropometric parameters such as body length and shoulder width. During the analysis, a number of parameters having zero influence were established, that is, they are not found in the group of persons under study. In this regard, the above parameters were not taken into account.

An analysis of the results of a nonparametric study showed correlation between anthropometric and dermatoglifical parameters of middle and proximal phalanges of fingers. For example, it is established that the length of the leg in the group under study correlates with such signs as: MF4LeftVm (-0,54), PF1LeftLu (-0,47), PF4LeftVm (-0,59), PF5RightS (-0,53), PF5RightLu (-0,54). Also, the length of the leg correlates with the height $(0.88)$, which is the foreseeable result, and indirectly confirms the results of the analysis. It should be noted that the sign near the correlation coefficient shows the connection vector between the variables.

Taking into account the obtained values of Spirman correlation coefficients for a pair of signs (as an example, the length of the leg / PF4LeftVm), the value -0.59 can be interpreted as a sufficiently strong dependence [6]. That is, the results of the analysis show that when detecting the sign $\mathrm{Vm}$ on the proximal phalanx of the fourth finger of the left hand, the leg length will «decrease». 

(Table 1).

Data of the non-parametric analysis were refined with a more flexible and precise method, namely regression analysis

Processing the results obtained using this method only results with a high level of reliability were taken into account the value of $\mathrm{p}$ (p-value) was within the range of $0.00 \quad 00<\mathrm{p}<0.05$. The determination coefficient (coefficient of determination) of $\mathrm{R}^{2}$ was within the limits $75<\mathrm{R}^{2}<, 100$ (that is, the constructed models describe at least $75 \%$ variability). Output data were checked for normal distribution of residues (residuals).

An estimation of the independence of the residues from the predicted values was also carried out. The standardized study error does not exceed $10 \%$.

In general, the regression equation has the form

$$
Y=b_{0}+b_{1} X_{1}+b_{2} X_{2}+. .+b_{n} X_{n}
$$

For example, when searching for the predicted length of the leg in the group under study (Lemko, women) according to the signs of proximal phalanges, the regression equation (data given in Table 1) will take the form

$$
Y=94,33-15,18 P F 1 L e f t L u-11,04 P F 4 L e f t V m-11,25 P F 2 L e f t L u-8,33 P F 2 \text { LeftAdr }
$$

To check this expression we will substitute the data from the control sample instead of signs 1 or 0 ( 1 - a case where the sign is observed in the subject, 0 - the sign is absent). It should also be taken into account that only one sign can be observed on a particular finger. As a result, for a control group with signs on the left hand we receive:

1) $\mathrm{Hdr}, \mathrm{Fu}, \mathrm{Vm}, \mathrm{Vm}, \mathrm{Vu}$ and leg length $86 \mathrm{~cm}$ :

$$
Y=94,33-15,18 * 0-11,04 * 1-11,25 * 0-8,33 * 0=83.29(\mathrm{~cm})
$$

2) $\mathrm{Lu}, \mathrm{ApNu}, \mathrm{ApNr}, \mathrm{Hdr}, \mathrm{Lu}$ and leg length $84 \mathrm{~cm}$ :

$$
Y=94,33-15,18 * 1-11,04 * 0-11,25 * 0-8,33 * 0=79.15(\mathrm{~cm})
$$

3) ApNr, Adr, ApNu, Hdr, ApNr Lu and leg length $86 \mathrm{~cm}$ :

$$
Y=94,33-15,18 * 0-11,04 * 0-11,25 * 0-8,33 * 1=86.0(\mathrm{~cm})
$$

\begin{tabular}{|c|c|c|c|}
\hline \multicolumn{2}{|c|}{ Middle phalang } & \multicolumn{2}{|c|}{ Proximal phalang } \\
\hline Sign & Coefficient influence & Sign & Coefficient influence \\
\hline \multicolumn{2}{|c|}{ Growth $/ b=163,17$} & \multicolumn{2}{|c|}{ Growth $/ \mathrm{b}=164,11$} \\
\hline MF3LeftVm & $-107,17$ & PF1LeftLu & $-66,33$ \\
\hline & & PF3RightS & 45,66 \\
\hline & & PF2LeftLu & $-29,22$ \\
\hline & & PF1LeftVr & $-40,78$ \\
\hline \multicolumn{2}{|c|}{ Body length $/ \mathrm{b}=55,70$} & \multicolumn{2}{|c|}{ Body length $/ \mathrm{b}=57,07$} \\
\hline \multirow[t]{3}{*}{ MF3LeftVm } & $-18,70$ & PF3LeftApNu & $-8,95$ \\
\hline & & RIGHT4W & $-7,41$ \\
\hline & & PF2RightVr & 10,88 \\
\hline \multicolumn{2}{|c|}{ Shoulder width $/ \mathrm{b}=37,94$} & \multicolumn{2}{|c|}{ Shoulder width $/ \mathrm{b}=37,55$} \\
\hline \multirow[t]{3}{*}{ MF3LeftVm } & $-13,94$ & PF1LeftLu & $-10,37$ \\
\hline & & PF3RightS & 1,72 \\
\hline & & PF1LeftVr & $-6,18$ \\
\hline \multicolumn{2}{|c|}{ Foot length $/ \mathrm{b}=24,29$} & \multicolumn{2}{|c|}{ Foot length $/ \mathrm{b}=24,31$} \\
\hline MF3LeftVm & $-8,29$ & PF1RightS & $-4,31$ \\
\hline \multicolumn{2}{|c|}{ Palm length $/ \mathrm{b}=17,41$} & \multicolumn{2}{|c|}{ Palm length $/ \mathrm{b}=17,37$} \\
\hline MF3LeftVm & 48,58 & PF1RightS & 24,62 \\
\hline \multicolumn{2}{|c|}{ Arm length $/ \mathrm{b}=88,82$} & \multicolumn{2}{|c|}{ Arm length $/ \mathrm{b}=94,33$} \\
\hline \multirow[t]{4}{*}{ MF3LeftVm } & $-36,82$ & PF1LeftLu & $-15,18$ \\
\hline & & PF4LeftVm & $-11,04$ \\
\hline & & PF2LeftLu & $-11,25$ \\
\hline & & PF2LeftAdr & $-8,33$ \\
\hline
\end{tabular}

Table 1

Summary table of the results of multiple regression for women of the Lemko ethno-territorial group (sign+ shows a positive correlation, a sign -is a negative correlation)

Thus, we see that the predicted result $X$ of the length of the leg varies within $[4+X-4] \mathrm{cm}$, with an error estimate of $<5 \%$, which is a fairly good result. 
As a result of the conducted researches groups of dermatoglyphic signs that correlate with anthropometric features are revealed. For the studied group of individuals there is a clear, mostly negative connection between the sign Vm in the middle phalanges and the anthropometric parameters. The main features of proximal phalanges that correlate with anthropometric parameters are Lu, Vr, Vm, Adr, ApNu S, Hdr.

Having conducted a similar study among men of the gender group, it was established, that for men of this group there is a stable correlation between the appearance of signs of $\mathrm{ApNu}$ and $\mathrm{ApNr}$ and such anthropometric parameters as height, body length and shoulder width which in turn correlate with each other - that is, there is a direct relationship between height and length of the body. Also, there are links between the features of Dhu in the middle phalanx and the length of the foot and palm. The appearance of the Adu sign on the proximal phalanges correlates with height, length of arm and shoulder width. Moderate correlation with anthropodatas is also observed in the signs Lr, Hdr, Adu, Dhu.

The obtained results of multiple regression for men of the Lemko ethno-territorial group are given in tab. 2.

Having conducted a comparative analysis of the results obtained for female and male gender groups, it can be concluded that the ApNu sign correlates with anthropometric parameters in both gender groups. Also, in both groups, the high level of communication with the sign of Hdr.

In the discussed aspect, it is very important to study the correlation between dermatological and anthropometric parameters, as well as the possibility of their use as prognostic features in the study of the phenotypology of an unknown person. Because along with the basic identification methods, the resolution of the method of dermatoglyphics can become more effective and reliable in attracting additional system of attributes.

Table 2

Summary table of the results of multiple regression for men of the Lemko ethno-territorial group (the + sign shows a positive correlation, the sign- is a negative correlation)

\begin{tabular}{|c|c|c|c|}
\hline \multicolumn{2}{|c|}{ Middle phalang } & \multicolumn{2}{|c|}{ Proximal phalang } \\
\hline Sign & Influence factor & Sign & Influence factor \\
\hline \multicolumn{2}{|c|}{ Growth $/ \mathrm{b}=163,17$} & \multicolumn{2}{|c|}{ Growth $/ \mathrm{b}=171,40$} \\
\hline \multirow[t]{4}{*}{ MF3LeftApNu } & 12,10 & PF1LeftAdu & 15,60 \\
\hline & & PF3LeftApNu & 14,10 \\
\hline & & PF3RightApNr & 7,60 \\
\hline & & PF5LeftApNu & 9,60 \\
\hline \multicolumn{2}{|c|}{ Body length $/ \mathrm{b}=58,70$} & \multicolumn{2}{|c|}{ Body length $/ \mathrm{b}=62,66$} \\
\hline \multirow[t]{2}{*}{ MF3LeftApNu } & 15,30 & PF3RightApNr & $-10,16$ \\
\hline & & PF3LeftApNu & 9,25 \\
\hline \multicolumn{2}{|c|}{ Shoulder width $/ \mathrm{b}=48,50$} & \multicolumn{2}{|c|}{ Shoulder width $/ \mathrm{b}=46,57$} \\
\hline \multirow[t]{3}{*}{ MF4RightLr } & 4,50 & PF1LeftAdu & 6,28 \\
\hline & & PF3RightApNu & $-4,07$ \\
\hline & & PF4RightLr & $-3,71$ \\
\hline \multicolumn{2}{|c|}{ Foot length $/ \mathrm{b}=29,62$} & \multicolumn{2}{|c|}{ Foot length / $b=29,62$} \\
\hline MF2LeftDhu & $-5,50$ & PF1LeftHdr & $-5,50$ \\
\hline \multicolumn{2}{|c|}{ Palm length $/ \mathrm{b}=20,37$} & \multicolumn{2}{|c|}{ Palm length $/ \mathrm{b}=20,20$} \\
\hline MF2LeftDhu & 13,12 & PF3RightApNr & 27,30 \\
\hline \multicolumn{2}{|c|}{ Arm length $/ \mathrm{b}=69,94$} & \multicolumn{2}{|c|}{ Arm length $/ \mathrm{b}=81,83$} \\
\hline MF3LeftHdu & $-9,90$ & PF2LeftAdu & $-9,83$ \\
\hline
\end{tabular}

Thus, the successful use of dermatoglyphics to identify an unknown person, along with other methods, allows you to speak about a system of methods that effectively complement each other. In addition, insufficient development, practical necessity, simplicity, non-invasiveness and material non-severity of the method determine the choice of finger dermatoglyphics when searching for criteria for diagnosis and markers for the manifestation of the phenotype.

\section{Література}

1. Хить ГЛ, Долинова НА. Расовая дифференциация человечества (Дерматоглифические данные). Rасе differentiation of humanity (Dermatoglyphic data). Москва: Наука; 1990. 206 с.

2. Хить ГЛ. Дерматоглифика народов Средней Азии в связи с проблемами их происхождения. Тезисы докладов на сессии, посвященной итогам полевых этнографических и антропологических исследований в 1974-1975 гг. Душанбе; 1976. С. 46-7

3. Сидоренко АГ. Возможности ладонной дерматоглифики при судебно-медицинской идентификации личности 
[автореферат]. Москва; 2006. 25 с.

4. Сегеда СП. Антропологический состав украинского народа: этногенетический аспект [автореферат]. Киев; 2002. $31 \mathrm{c}$.

5. Шпак ЛЮ. Дерматоглифика фаланг пальцев кисти (антропологические и судебно-медицинские аспекты) [автореферат]. Москва; 2003. 24 с.

6. Armitage P, Colton T, editors. Encyclopedia of Biostatistics; 1998. Zar JH. Spearman rank correlation. p. 578-81

7. Bilodeau M, Brenner D. Theory of multivariate statistics. Springer; 2008. 123 p.

\title{
References
}

1. Khit' GL, Dolinova NA. Rasovaya differentsiatsiya chelovechestva (Dermatoglificheskie dannye) [Race differentiation of humanity (Dermatoglyphic data)]. Moskva: Nauka; 1990. 206 s. (in Russian)

2. Khit' GL. Dermatoglifika narodov Sredney Azii v svyazi s problemami ikh proiskhozhdeniya [Dermatoglyctics of the peoples of Central Asia in connection with problems of their origin]. Tezisy dokladov na sessii, posvyashchennoy itogam polevykh etnograficheskikh i antropologicheskikh issledovaniy v 1974-1975 gg. Dushanbe; 1976. s. 46-7. (in Russian)

3. Sidorenko AG. Vozmozhnosti ladonnoy dermatoglifiki pri sudebno-meditsinskoy identifikatsii lichnosti [Possibilities of palmar dermatoglyphics in forensic identification] [avtoreferat]. Moskva; 2006. 22 s. (in Russian)

4. Segeda SP. Antropologicheskiy sostav ukrainskogo naroda: etnogeneticheskiy aspekt [Anthropological composition of the Ukrainian people: ethnogenetic aspect] [avtoreferat]. Kiev; 2002. 28 s. (in Russian)

5. Shpak LYu. Dermatoglifika falang pal'tsev kisti (antropologicheskie i sudebno-meditsinskie aspekty) [Dermatoglyphic phalanges of the fingers (anthropological and forensic medical aspects)] [avtoreferat]. Moskva; 2003. $25 \mathrm{~s}$. (in Russian)

6. Armitage P, Colton T, editors. Encyclopedia of Biostatistics; 1998. Zar JH. Spearman rank correlation. p. 578-81

7. Bilodeau M, Brenner D. Theory of multivariate statistics. Springer; 2008. 123 p.

\section{ГЕНДЕРНА ДИФЕРЕНЦАЦІЯ ФАКТОРНИХ КРИТЕРІЇВ ДЕРМАТОГЛІФІЧНИХ ПАРАМЕТРІВ СЕРЕДНІХ ТА ПРОКСИМАЛЬНИХ ФАЛАНГ ПАЛЬЦІВ РУК У ОСІБ, ЩО НАЛЕЖАТЬ ДО ЛЕМКІВСЬКОЇ ЕТНО-ТЕРИТОРІАЛЬНОЇ ГРУПИ}

\author{
Коцюбинська Ю. 3.
}

Резюме. У запропонованій статті представлені дані, отримані у ході вивчення гендерної диференціації дерматогліфічних параметрів середніх та проксимальних фаланг пальців рук у осіб, що належать до лемківської етно-територіальної групи. А також, запропоновано можливість використання отриманих даних з метою прогнозування фенотипології невідомоїособи.

Ключові слова: дерматогліфічні параметри, етнодерматогліфіка, критерій Спірмена.

\section{ГЕНДЕРНАЯ ДИФФЕРЕНИФЦИЯ ФАЕТОРНЫХ КРИТЕРИЕВ ДЕРМАТОГЛИФИЧЕСКИХ ПАРАМЕТРОВ СРЕДНИХ И ПРОКСИМАЛЬНЫХ ФАЛАНГ ПАЛЬЦЕВ РУК У ЛИЦ, ПРИНАДЛЕЖАЩИХ К ЛЕМКОВСКОЙ ЭТНО-ТЕРРИТОРИАЛЬНОЙ ГРУППЕ}

\author{
Коцюбинская Ю. 3.
}

Резюме. В предлагаемой статье представлены данные, полученные в ходе изучения гендерной дифференциации дерматоглифических параметров средних и проксимальных фаланг пальцев рук у лиц, принадлежащих к лемковской этнотерриториальной группы. А также, представленная возможность использования полученных данных для прогнозирования фенотипологии неизвестного лица.

Ключевые слова: дерматоглифические параметры, етнодерматоглифика, критерий Спирмена. 